\title{
Status mutu air dan beban pencemaran Sungai Krukut, DKI Jakarta
}

\author{
Water quality status and pollution load of Krukut River, Jakarta Province
}

\author{
Intan P. Rachmawati ${ }^{\mathrm{a}}$, Etty Riani ${ }^{\mathrm{b}}$, Agung Riadi \\ ${ }^{a}$ Departemen Pengelolaan Sumber Daya Alam dan Lingkungan, Institut Pertanian Bogor, Kampus IPB Darmaga Bogor, 16680, \\ Indonesia [+6281904131052] \\ ${ }^{\mathrm{b}}$ Departemen Manajemen Sumberdaya Perairan, Fakultas Perikanan dan Ilmu Kelautan, Institut Pertanian Bogor, Kampus IPB \\ Darmaga Bogor, 16680, Indonesia \\ ${ }^{c}$ Pusat Teknologi Lingkungan - Badan Pengkajian dan Penerapan Teknologi, Serpong, Tangerang Selatan, Indonesia
}

\section{Article Info:}

Received: 18 - 01 - 2017

Accepted: 12 - 05 - 2020

\section{Keywords:}

Water quality, IP, pollution load, Krukut River

\section{Corresponding Author:} Intan Pramudita Rachmawati Departemen Pengelolaan Sumber Daya Alam dan

Lingkungan, Institut Pertanian Bogor;

Tel. +6281904131052

Email:

intan.pramudita@gmail.com

\begin{abstract}
In Indonesia, Rivers experience shifted functions, especially those located in Jakarta. As a capital, the rapid population growth and the high migration rate are unavoidable. This circumstance contributes to the degradation of environment quality including water in the rivers. Krukut river is one of those flowing down to Jakarta and has an important role in supporting the life of people. This river is intended to be the drinking water sources (based on DKI Jakarta governour decision no. 582/1995). Hence, this research aims to understand the status of water quality and potential contamination load of Krukut river. The quality of water was assessed by using the contamination index (following the MoE decision no 115 year 2003). The quality standard used is class I and Class II. Data collection was carried out in April 2015 in nine different observation points. Our analysis found that the water quality standard within class I was heavily contaminated in all observation points. Meanwhile, standard quality II is in heavy to medium contamination rate. The potential domestic contamination load in the river was found high reaching up to $203562.89 \mathrm{~kg} /$ day, $275814.4 \mathrm{~kg} /$ day and $190562.7 \mathrm{~kg} /$ day for BOD, COD and TSS values respectively. The contamination load was suggested to come from the domestice household wastes.
\end{abstract}

How to cite (CSE Style $8^{\text {th }}$ Edition):

Rachmawati IP, Riani E, Riadi A. 2020. Status mutu air dan beban pencemaran Sungai Krukut, DKI Jakarta. JPSL 10(2): $220-233$. http://dx.doi.org/10.29244/jpsl.10.2.220-233.

\section{PENDAHULUAN}

Sungai memiliki banyak peranan untuk menunjang aktivitas manusia. Sumber daya air sungai dapat dimanfaatkan sebagai sumber air untuk memenuhi kebutuhan hidup manusia sehari-hari seperti untuk mandi, mencuci, bahkan sebagai air minum. Sungai juga dapat dimanfaatkan sebagai pembangkit tenaga listrik, sebagai tempat pariwisata, dan transportasi. Seiring dengan laju pembangunan dan pertumbuhan penduduk, sungai menjadi beralih fungsi menjadi tempat akumulasi pembuangan limbah dari semua aktivitas manusia, terutama di wilayah perkotaan. Hal tersebut menyebabkan bahan pencemar akan masuk ke aliran sungai sebelum akhirnya dialirkan ke laut ataupun danau, dan pada titik tertentu ketika daya tampung sungai terhadap beban pencemaran sudah mencapai batasnya maka yang akan terjadi adalah pencemaran sungai yang akan menimbulkan berbagai masalah baru. 
Pergeseran fungsi sungai terjadi di wilayah DKI Jakarta. Sebagai ibukota negara, laju pembangunan dan pertumbuhan penduduk, serta laju migrasi menjadi sesuatu yang tidak dapat dihindari. Kepadatan penduduk di ibukota turut berkontribusi pada penurunan kualitas lingkungan termasuk kualitas sungai. Kinerja perekonomian Provinsi DKI Jakarta sebagai pusat pemerintahan dan kegiatan perekonomian di Indonesia menunjukkan perkembangan fluktuatif dari tahun 2006 hingga 2013 dengan kecenderungan meningkat. Ratarata pertumbuhan ekonomi selama periode tersebut sebesar 6.33\% lebih tinggi dari laju pertumbuhan ekonomi rata-rata nasional (PDB Nasional) sebesar 5.90\%. Sebagai pusat ekonomi dan pemerintahan, pertumbuhan ekonomi Jakarta relatif lebih tinggi dibandingkan kota-kota lain di Indonesia (Bappeda Provinsi DKI Jakarta, 2015).

Sungai Krukut sebagai salah satu sungai besar yang mengalir di wilayah ibukota memiliki peran penting untuk menunjang aktivitas masyarakat di ibukota, dan diperuntukkan sebagai air baku air minum (Pergub DKI Jakarta No 582/1995) yang dikelola bekerjasama dengan PT. PAM Jaya. Selain itu juga Sungai Krukut merupakan salah satu dari empat sungai di Jakarta yang menjadi sasaran Master Plan Peningkatan Kualitas Air Sungai Jakarta 2015 oleh BPLHD DKI Jakarta. Kualitas air Sungai Krukut semakin menurun seiring dengan bertambahnya jumlah penduduk di DKI Jakarta. Berbagai aktivitas manusia dalam memenuhi kebutuhan hidupnya yang berasal dari kegiatan industri, rumah tangga, dan pertanian akan menghasilkan limbah yang memberi sumbangan penurunan kualitas air sungai (Suriawira, 2003). Produksi limbah yang dihasilkan dari aktivitas manusia, khususnya limbah cair yang dibuang ke sungai secara terus menerus turut berperan dalam penurunan daya dukung dan kualitas lingkungan di Kota Jakarta. Penurunan kualitas air sungai ini dapat disebabkan karena meningkatnya jumlah masukan limbah ke badan sungai baik yang berasal dari limbah domestik maupun industri. Limbah domestik dapat berupa buangan air rumah tangga, padatan berupa sampah yang dibuang ke sungai, air cucian kamar mandi maupun buangan tinja yang akan mempengaruhi tingkat kandungan BOD, COD serta bakteri E. Coli dalam sungai (Hendrawan, 2005). Pencemaran yang terjadi di sungai, merupakan masalah penting yang perlu memperoleh perhatian dari berbagai pihak. Semakin menurun kualitas air Sungai Krukut menyebabkan semakin buruk kualitas air untuk baku air minum bagi masyarakat. Walaupun di Indonesia belum terdapat kasus yang mengungkap masyarakat keracunan akibat minum air yang berasal PAM, namun UNICEF menyebutkan bahwa setiap tahunnya ada sekitar 5 juta anak yang tewas di negara berkembang karena keracunan air minum (Susmarkanto, 2002). Di samping itu pencemaran yang terjadi di Sungai Krukut juga mengurangi estetika sungai oleh banyaknya sampah yang ada di permukaan sungai dan disertai bau tidak sedap dari sampah yang terakumulasi. Oleh karena, itu penelitian ini penting untuk dilakukan. Tujuan dari penelitian ini adalah untuk menganalisis status mutu air Sungai Krukut menggunakan Indeks Pencemaran.

\section{METODE}

\section{Lokasi dan Waktu Penelitian}

Penelitian ini dilakukan di Sungai Krukut wilayah DAS Krukut segmen DKI Jakarta. Sungai Krukut mengalir melewati beberapa kecamatan di Jakarta dan bermuara pada banjir kanal barat. Panjang Sungai Krukut yang terdapat pada penelitian ini ialah 18.49 kilometer $(\mathrm{km})$ dan memiliki hulu di Kecamatan Jagarasa yang berbatasan dengan wilayah administrasi Kota Depok. Data kualitas air diambil pada Bulan April 2015, pada 9 stasiun sesuai dengan yang telah ditentukan oleh Badan Pengelolaan Lingkungan Hidup DKI Jakarta (BPLHD DKI Jakarta).

\section{Metode Pengumpulan Data}

Pengambilan sampel dilakukan dengan metode grab sampling, yaitu hanya sekali pengambilan sampel. Titik lokasi pengambilan sampel merupakan lokasi percabangan sungai dan titik lokasi outlet saluran drainase yang masuk ke badan sungai. Lokasi 9 stasiun pemantauan dapat dilihat pada Tabel 1. 
Tabel 1 Lokasi koordinat staiun pemantauan

\begin{tabular}{ccc}
\hline \multirow{2}{*}{ Stasiun } & \multicolumn{2}{c}{ Koordinat Lokasi } \\
\cline { 2 - 3 } & Bujur & Lintang \\
\hline Stasiun 1 & $106^{\circ} 47^{\prime} 53.395^{\prime \prime} \mathrm{E}$ & $6^{\circ} 20^{\prime} 40.720^{\prime \prime} \mathrm{S}$ \\
\hline Stasiun 2 & $106^{\circ} 48^{\prime} 26.218^{\prime \prime} \mathrm{E}$ & $6^{\circ} 19^{\prime} 15.165^{\prime \prime} \mathrm{S}$ \\
\hline Stasiun 3 & $106^{\circ} 48^{\prime} 30.191^{\prime \prime} \mathrm{E}$ & $6^{\circ} 18^{\prime} 25.549^{\prime \prime} \mathrm{S}$ \\
\hline Stasiun 4 & $106^{\circ} 48^{\prime} 19.289^{\prime \prime} \mathrm{E}$ & $6^{\circ} 17^{\prime} 50.916^{\prime \prime} \mathrm{S}$ \\
\hline Stasiun 5 & $106^{\circ} 48^{\prime} 34.792^{\prime \prime} \mathrm{E}$ & $6^{\circ} 17^{\prime} 9.064^{\prime \prime} \mathrm{S}$ \\
\hline Stasiun 6 & $106^{\circ} 48^{\prime} 30.438^{\prime \prime} \mathrm{E}$ & $6^{\circ} 15^{\prime} 18.669^{\prime \prime} \mathrm{S}$ \\
\hline Stasiun 7 & $106^{\circ} 48^{\prime} 44.100^{\prime \prime} \mathrm{E}$ & $6^{\circ} 14^{\prime} 48.586^{\prime \prime} \mathrm{S}$ \\
\hline Stasiun 8 & $106^{\circ} 49^{\prime} 4.108^{\prime \prime} \mathrm{E}$ & $6^{\circ} 13^{\prime} 59.181^{\prime \prime} \mathrm{S}$ \\
\hline Stasiun 9 & $106^{\circ} 48^{\prime} 39.752^{\prime \prime} \mathrm{E}$ & $6^{\circ} 11^{\prime} 57.667^{\prime \prime} \mathrm{S}$ \\
\hline
\end{tabular}

Parameter kualitas air yang diamati dalam penelitian ini diantaranya ialah parameter fisik meliputi suhu, TDS, dan TSS. Parameter kimia meliputi pH, BOD, COD, dan DO, serta parameter biologi meliputi bakteri coli dan bakteri fecal coli. Lokasi penelitian dapat dilihat pada Gambar 1.

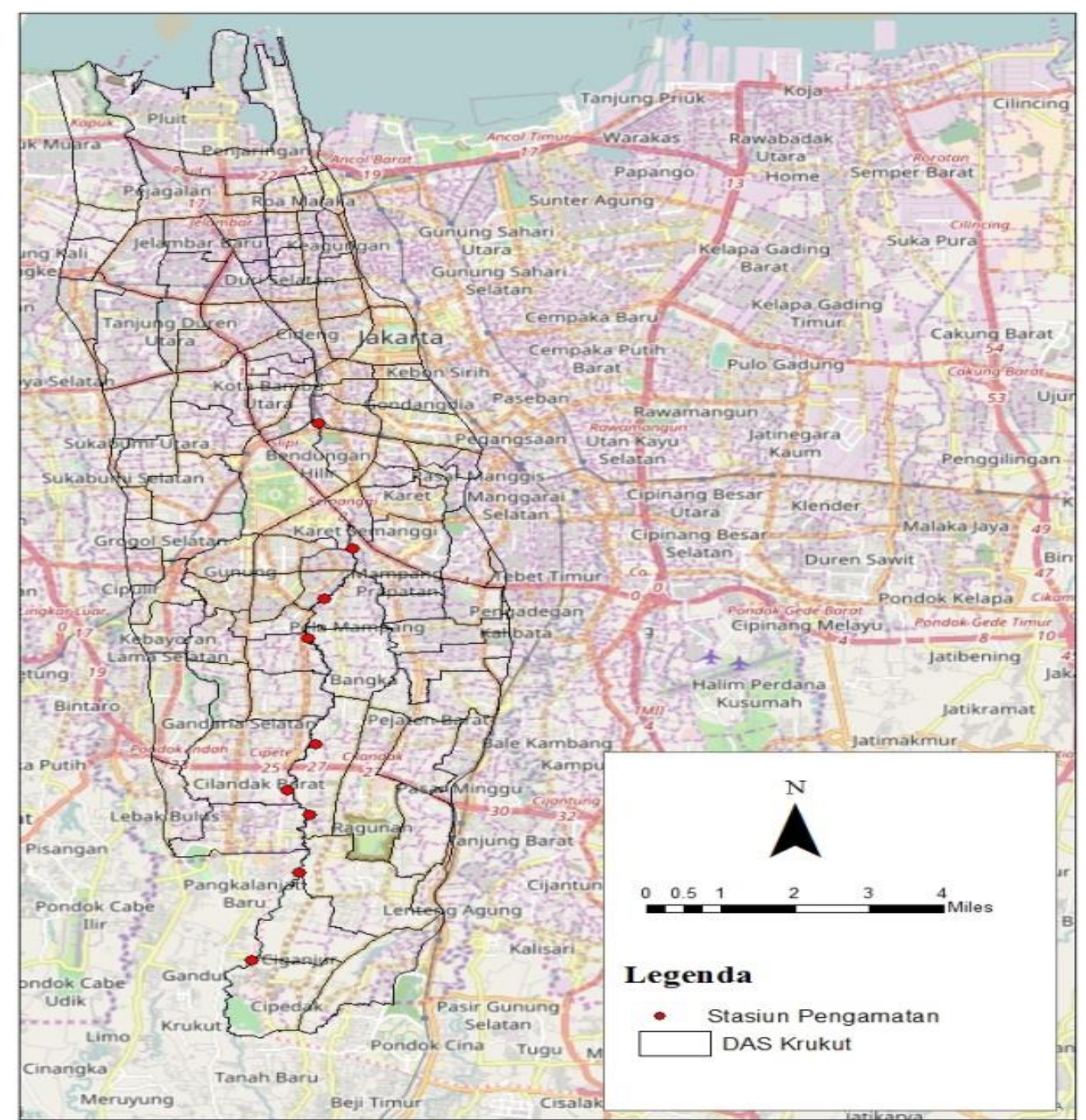

Gambar 1 Peta lokasi penelitian 


\section{Metode Analisis Data}

\section{Analisis Status Mutu Air Sungai Krukut}

Status mutu Air Sungai Krukut akan dihitung menggunakan metode Indeks Pencemaran (IP) atau Nemerow Pollution Index (NPI) (Nemerow, 1974; Effendi et al., 2015) sesuai dengan Keputusan Menteri Negara Lingkungan Hidup Nomor 115 Tahun 2003 Tentang Pedoman Penentuan Status Mutu Air. Persamaan IP ialah sebagai berikut:

$$
I P_{j}=\sqrt{\frac{\left(C_{i} / L_{i j}\right)_{M}{ }^{2}+\left(C_{i} / L_{i j}\right)_{R}{ }^{2}}{2}}
$$

Hasil dari perhitungan dievaluasi sesuai dengan tabel penilaian IP (Tabel 2) sebagai berikut:

Tabel 2 Penentuan status mutu air Metode Indeks Pencemaran (IP)

\begin{tabular}{ccc}
\hline No & Nilai & Status \\
\hline 1 & $0 \leq \mathrm{Pij} \leq 1.0$ & memenuhi baku mutu \\
2 & $1.0<\mathrm{Pij} \leq 5.0$ & tercemar ringan \\
3 & $5.0<\mathrm{Pij} \leq 10.0$ & tercemar sedang \\
4 & $\mathrm{Pij} \geq 10.0$ & tercemar berat \\
\hline
\end{tabular}

Sumber: KepMenLH 115/2003

Berdasarkan Peraturan Gubernur DKI No 582/1995 bahwa peruntukan air Sugai Krukut ialah sebagai air baku air minum maka analisis status mutu dilakukan dengan menggunakan baku mutu air (BMA) kelas I, sedangkan analisis dengan menggunakan BMA kelas II dilakukan sebagai komparasi kondisi kualitas air Sungai Krukut apabila digunakan baku mutu yang setingkat lebih rendah. Baku mutu yang digunakan ialah yang telah diatur pada Peraturan Pemerintah No 82 Tahun 2001. Baku mutu yang digunakan tidak mengacu pada Peraturan Gubernur DKI No 582/1995 dikarenakan peraturan tersebut sudah terlalu tua dan belum diperbarui selama kurun waktu 21 tahun sehingga dinilai kurang relevan untuk digunakan sebagai baku mutu melihat kondisi pertumbuhan dan pembangunan di DKI Jakarta yang sudah jauh sangat berkembang dibandingkan dengan tahun-tahun sebelumnya.

\section{Potensi Beban Pencemaran}

Potensi Beban Pencemaran (PBP) di Sungai Krukut bersumber dari kegiatan domestik. Perhitungan PBP dari sumber rumah tangga menggunakan rumus yang mengacu pada Balai Lingkungan Pengairan PUSLITBANG SDA, Kementrian PU (Iskandar, 2007) adalah sebagai berikut:

$$
P B P=\alpha \times \text { jumlah penduduk } \times \text { faktor effluent } \times \text { rek }
$$

$\alpha$ merupakan koefisien transfer beban yang menyatakan tingkat kemudahan limbah mencapai sungai. Nilainya berkisar antara 0.3 hingga 0.1 . Semakin mudah limbah mencapai sungai maka semakin besar nilai $\alpha$. Nilai $\alpha=1$ digunakan untuk daerah yang lokasinya berjarak antara 0 sampai dengan 100 meter dari sungai. Nilai $\alpha=0.85$ untuk lokasi yang berjarak antara 100 sampai dengan 500 meter dari sungai. Nilai $\alpha=0.3$ untuk lokasi yang berjarak lebih besar dari 50 meter dari sungai. Nilai faktor effluent dari masing-masing parameter: 1) $\mathrm{BOD}=40$ gram/orang/hari; $\mathrm{COD}=55$ gram/orang/hari; $\mathrm{TSS}=38$ gram/orang/hari. Nilai faktor effluen ini diperoleh berdasarkan survei di Jakarta tahun 1989, tiap orang rata-rata mengeluarkan beban limbah organik sebesar 40 gram BOD per orang per hari, yakni dari limbah toilet 13 gram per orang per hari dan dari limbah non toilet sebesar 27 gram BOD per orang per hari (Setiyono, 2014), dan diperkuat oleh Mara (2004) yang menyatakan bahwa nilai BOD yang baik untuk digunakan di negara berkembang ialah 40 gram/orang/hari. 
Rek = Rasio ekivalensi kota yang menyatakan perbedaan beban limbah domestik yang dihasilkan antara wilayah perkotaan, pinggiran dan pedalaman, nilai rasio ekuivalensi ialah: 1) Kota $=1$; 2) Pinggiran kota $=$ $0.8125 ;$ Pedalaman $=0.625$.

\section{HASIL DAN PEMBAHASAN}

\section{Hasil}

Nilai parameter kualitas air Sungai Krukut DKI Jakarta dapat dilihat pada Tabel 3.

Tabel 3 Nilai parameter kualitas air Sungai Krukut

\begin{tabular}{|c|c|c|c|c|c|c|c|c|c|c|c|c|}
\hline No & Parameter & $\begin{array}{c}\text { Baku } \\
\text { Mutu } \\
\text { Kelas I }\end{array}$ & $\begin{array}{c}\text { Baku } \\
\text { Mutu } \\
\text { Kelas II }\end{array}$ & $\begin{array}{c}\text { Stasiun } \\
1\end{array}$ & $\begin{array}{c}\text { Stasiun } \\
2\end{array}$ & $\begin{array}{c}\text { Stasiun } \\
3\end{array}$ & $\begin{array}{c}\text { Stasiun } \\
4\end{array}$ & $\begin{array}{c}\text { Stasiun } \\
5\end{array}$ & $\begin{array}{c}\text { Stasiun } \\
6\end{array}$ & $\begin{array}{c}\text { Stasiun } \\
7\end{array}$ & $\begin{array}{c}\text { Stasiun } \\
8\end{array}$ & $\begin{array}{c}\text { Stasiun } \\
9\end{array}$ \\
\hline 1 & Suhu & $\begin{array}{c}\text { Deviasi } \\
3\end{array}$ & $\begin{array}{c}\text { Deviasi } \\
3\end{array}$ & 28.65 & 28.25 & 28.00 & 28.35 & 28.00 & 28.40 & 24.90 & 28.90 & 27.90 \\
\hline 2 & $\mathrm{pH}$ & $6-9$ & $6-9$ & 7.2 & 6.9 & 7.2 & 7.2 & 7.3 & 7.5 & 7.5 & 7.0 & 7.4 \\
\hline 3 & $\begin{array}{l}\text { Zat Padat } \\
\text { Terlarut } \\
\text { (TDS) } \\
\mathrm{mg} / \mathrm{L} \\
\end{array}$ & 1000 & 1000 & 102.5 & 112 & 113 & 112 & 129 & 155 & 150 & 222.0 & 197 \\
\hline 4 & $\begin{array}{l}\text { Zat Padat } \\
\text { Tersuspensi } \\
\text { (TSS) } \\
\mathrm{mg} / \mathrm{L}\end{array}$ & 50 & 50 & 20 & 19 & 29 & 28 & 35 & 31 & 16 & 24.0 & 33 \\
\hline 5 & $\begin{array}{l}\text { Oksigen } \\
\text { Terlarut (DO) } \\
\mathrm{mg} / \mathrm{L}\end{array}$ & 6 & 4 & 1.10 & 1.86 & 1.09 & 1.13 & 1.19 & 5.56 & 5.24 & 5.05 & 5.5 \\
\hline 6 & $\begin{array}{l}\mathrm{BOD}\left(20^{\circ} \mathrm{C}, 5\right. \\
\text { hari) } \\
\mathrm{mg} / \mathrm{L}\end{array}$ & 2 & 3 & 3.84 & 3.84 & 3.18 & 2.63 & 4.74 & 6.88 & 5.47 & 9.34 & 9.72 \\
\hline 7 & $\begin{array}{l}\text { COD } \\
\text { (dichromat) } \\
\mathrm{mg} / \mathrm{L}\end{array}$ & 10 & 25 & 7.1 & 10 & 8.9 & 6.4 & 11.8 & 11.9 & 14.6 & 35.10 & 22.3 \\
\hline 8 & $\begin{array}{l}\text { Coliform } \\
\mathrm{jml} / 100 \mathrm{ml}\end{array}$ & 1000 & 5000 & 690000 & 560000 & 520000 & 370000 & 129000 & 900000 & 87000 & 1440000 & 1700000 \\
\hline 9 & $\begin{array}{l}\text { Fecal } \\
\text { Colifom } \\
\text { jml/100 ml }\end{array}$ & 100 & 1000 & 130000 & 130000 & 120000 & 60000 & 44000 & 270000 & 41000 & 620000 & 740000 \\
\hline
\end{tabular}

\section{Suhu, TSS, dan TDS}

Temperatur air Sungai Krukut berkisar antara $24.8^{\circ} \mathrm{C}-25.4^{\circ} \mathrm{C}$. Suhu pada dasarnya penting untuk efek pada reaksi kimia dan biologi tertentu yang terjadi di air dan organisme akuatik (Saksena et al., 2008). Menurut Keputusan Menteri Kesehatan Republik Indonesia No.907/MENKES/SSK/V11/2002 tentang Syaratsyarat dan Pengawasan Kualitas Air Minum, syarat fisik air yang dapat dijadikan sumber air minum (air kelas 1) ialah harus jernih, tidak berwarna, tidak berasa, tidak berbau, temperature normal dan tidak mengandung zat padatan (dinyatakan dengan TSS dan TDS). Pada PP No.82/2001 disebutkan bahwa nilai TDS dan TSS yang memenuhi syarat sebagai air minum ialah $100 \mathrm{mg} / \mathrm{L}$ untuk TDS dan $50 \mathrm{mg} / \mathrm{L}$ untuk TSS. TDS dapat digunakan untuk memperkirakan kualitas air minum karena mewakili banyaknya ion di dalam air. TDS tinggi dan TSS dapat meningkatkan suhu air karena bahan padat menyerap panas dari sinar matahari (Martinez dan Galera, 2011).

Curah hujan dapat mengurangi nilai TSS karena dapat membantu pengenceran, akan tetapi dapat pula meningkatkan konsetrasi TSS bergantung pada kondisi DAS (Amneera et al., 2013). TSS dapat menyebabkan kekeruhan terhadap air (Said, 2008). Menurut Effendi et al. (2015) TSS terdiri atas lumpur dan pasir halus serta jasad-jasad renik, terutama disebabkan oleh kikisan tanah atau erosi tanah yang terbawa ke badan air. Nilai TSS berkisar antara 16-35mg/L, nilai TSS Sungai Krukut masih memenuhi baku mutu air kelas I maupun kelas II. Hal ini mengindikasikan bahwa Sungai Krukut belum terlalu tercemar oleh partikulat yang dapat meningkatkan kekeruhan. Rentang nilai TDS juga masih memenuhi baku mutu air kelas I dan kelas II yaitu 224 
berkisar antara 102.5-22.2 mg/L. Ruang terbuka berupa lahan kosong yang jumlahnya tidak terlalu banyak di wilayah sekitar stasiun-stasiun pemantauan membuat nilai TSS tidak telalu tinggi. Jika semakin luas lahan yang terbuka maka potensi terjadinya butiran air tanah yang terbawa run off ke sungai ketika hujan turun semakin besar. Hal itu dikarenakan oleh tidak adanya bangunan maupun vegetasi yang menghambat air hujan mengenai permukaan tanah secara langsung, dan tidak ada yang menahan laju aliran run off pada lahan yang terbuka.

\section{DO dan pH}

Nilai pH pada stasiun 1 hingga 9 berada pada rentang 6.9-7.5. Pada PP No 82/2002 disebutkan bahwa rentang nilai $\mathrm{pH}$ air kelas II ialah 6-9, oleh karena itu hasil pengukuran $\mathrm{pH}$ di lokasi pemantauan memenuhi kriteria baku mutu dan menunjukkan bahwa air Sungai Krukut masih berada pada kondisi baik untuk pemanfaatan air baku air minum maupun irigasi air sawah. Air yang memiliki $\mathrm{pH}$ sangat rendah dapat bersifat korosif dan dapat menyebabkan pengkaratan pada besi atau baja yang tentunya berbahaya bagi manusia. Nilai pH menjadi faktor yang penting dalam perairan karena nilai $\mathrm{pH}$ menggambarkan suasana asam atau basa pada air. Air yang baik untuk dijadikan air minum memiliki $\mathrm{pH}$ 6.5-8.5 sesuai dengan Permenkes No. 492/Menkes/Per/IV/2010. Jika dilihat dari kriteria nilai pH, pH air Sungai Krukut masih memenuhi kriteria untuk diolah sebagai air minum.

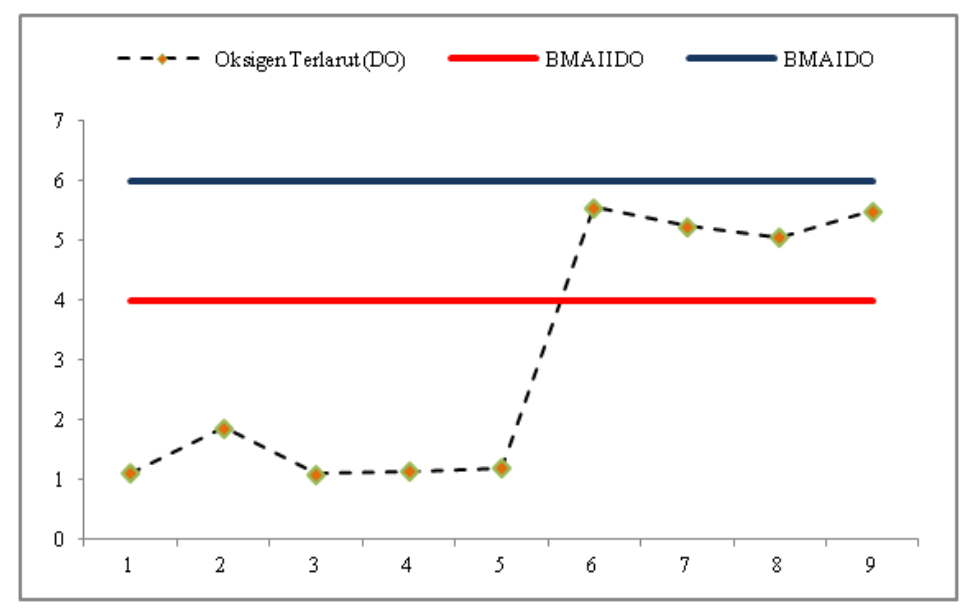

Gambar 2 Nilai DO Sungai Krukut, April 2015

Nilai DO Sungai Krukut dapat dilihat pada Gambar 2. DO merupakan kandungan oksigen yang terlarut di dalam air. Oksigen memegang peranan penting sebagai indikator kualitas perairan, karena oksigen terlarut berperan dalam proses oksidasi dan reduksi bahan organik dan anorganik, karena proses oksidasi dan reduksi inilah maka peranan oksigen terlarut sangat penting untuk membantu mengurangi beban pencemaran pada perairan secara alami maupun secara perlakuan aerobik yang ditujukan untuk mengurangi konsentrasi pencemar pada air buangan industri dan rumah tangga (Salmin, 2005). Hasil menunjukkan bahwa nilai DO dalam air Sungai Krukut pada stasiun 1 sampai dengan stasiun 5 telah melebihi batas minimum yang diperbolehkan untuk kelas I dan kelas II. Pada stasiun 6 sampai dengan stasiun 9 nilai DO masih berada pada rentang yang diperbolehkan untuk kelas II, namun sudah melebihi dari batas yang diperbolehkan untuk kelas I. Oleh karena itu, jika dilihat dari kriteria DO maka air Sungai Krukut tidak memenuhi kriteria sebagai bahan baku air minum, sehingga diperlukan treatment khusus untuk mengolah air Sungai Krukut agar dapat memenuhi kriteria untuk dikonsumsi sebagai air minum. 


\section{BOD dan COD}

Biochemical Oxigen Demand (BOD) merupakan jumlah oksigen yang digunakan oleh mikroorganisme untuk mendekomposisi materi organik dalam air pada kurun waktu lima hari (APHA, 2005). Semakin rendah kandungan BOD menandakan bahwa kandungan pencemar organik pada sungai tersebut rendah (Saksena et $a l ., 2008)$. Makin besar nilai BOD suatu perairan, menunjukkan konsentrasi bahan organik di dalam air juga tinggi. Parameter BOD, secara umum dipakai untuk menentukan tingkat pencemaran air buangan (Salmin, 2005). Wilayah sekitar di lokasi stasiun pemantauan merupakan wilayah permukiman dan banyak yang merupakan wilayah padat penduduk dengan rumah tinggal yang sangat mepet dengat badan sungai, sehingga limbah rumah tangga langsung dibuang ke badan sungai tanpa melalui IPAL terlebih dahulu. Nilai BOD berkisar antara 2.63-9.72 mg/L (Gambar 3) sehingga sudah tidak memenuhi baku mutu air kelas I maupun kelas II, dan air Sungai Krukut tidak memenuhi kriteria untuk dijadikan bahan baku air minum. Kondisi serupa terjadi pada Sungai Tarum Barat yang juga diperuntukkan sebagai bahan baku air minum (Pergub DKI Jakarta No. 582/1995), nilai BOD Sungai Tarum Barat berkisar antara 3.43-81.08 mg/L (SLHD DKI Jakarta, 2015). Kondisi tersebut lebih buruk jika dibandingkan dengan Sungai Metro Kabupaten Malang. Nilai BOD Sungai Metro berkisar antara 3.20-5.65 mg/L (Mahyudin et al., 2015). Apabila akan digunakan sebagai air baku air minum maka diperlukan pengolahan yang lebih baik sehingga air sungai dapat memenuhi kriteria yang telah ditentukan. Pengelolaan yang dilakukan tentunya memerlukan instalasi tertentu dan dengan biaya tidak murah. Pengelolaan air dilakukan oleh pihak terkait, dalam hal ini ialah PT. PAM Jaya.

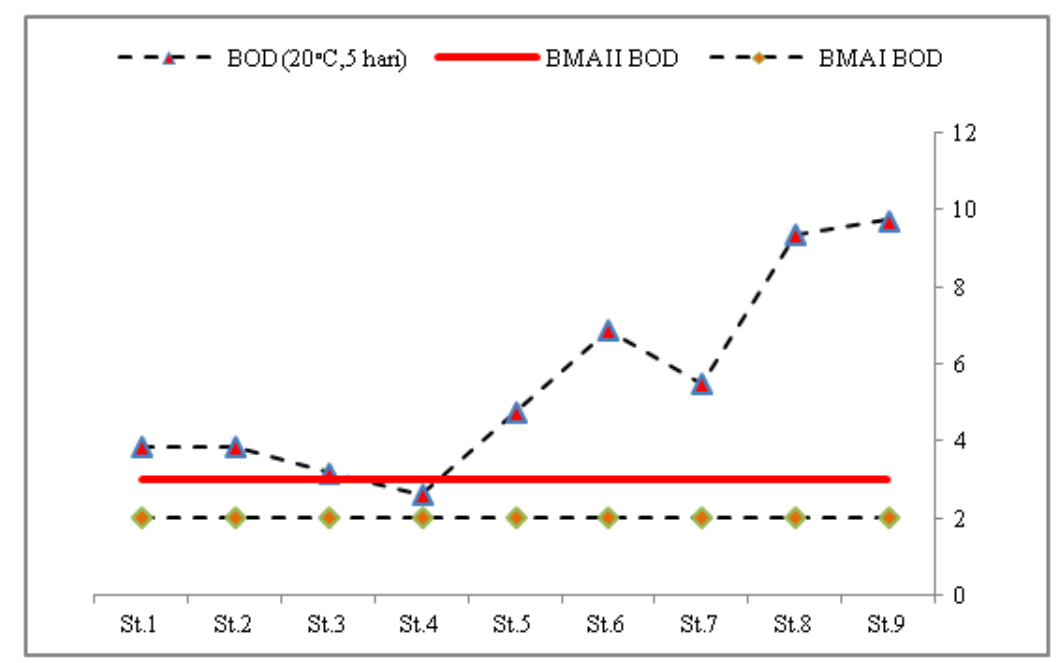

Gambar 3 Nilai BOD Sungai Krukut, April 2015

COD adalah banyaknya oksigen yang dibutuhkan untuk mengoksidasi bahan-bahan organik secara kimia (Yudo, 2010). Badan sungai yang mengandung COD maupun BOD yang tinggi mengindikasikan pencemaran di badan sungai tinggi. Nilai COD Sungai Krukut (Gambar 4) mulai meningkat melebihi baku mutu pada Stasiun 5 dan terus meningkat sampai Stasiun 8 dan turun pada Stasiun 9. Lokasi Stasiun 5 merupakan wilayah permukiman yang padat dan berjarak sangat dekat dengan badan sungai, sehingga limbah rumah tangga secara langsung dibuang ke badan sungai. Di lokasi tersebut juga ditemui kamar mandi umum yang berada tepat di pinggir sungai dan dekat dengan titik pengambilan sampel Stasiun 5, sehingga mengakibatkan nilai COD meningkat. Nilai COD Sungai Krukut di tujuh stasiun pemantauan masih memenuhi baku mutu air kelas II PP No. 82/2001 kecuali pada stasiun 8 dan 9, walaupun ada beberapa tempat yang nilai CODnya masih di bawah baku mutu untuk kelas II, secara umum hal ini menunjukkan bahwa Sungai Krukut telah tercemar oleh bahan organik yang sulit terurai. Apabila digunakan baku mutu air kelas I sebagai tolak ukur maka nilai COD sudah tidak memenuhi baku mutu mulai dari stasiun 5 sampai stasiun 9, dan nilai COD melonjak tinggi di atas baku mutu air kelas I. Pada bagian hilir nilai COD tinggi dapat disebabkan karena adanya akumulasi beban mulai 
dari bagian hulu, apabila tidak terjadi pengenceran selama perjalanan menuju hilir dan laju dekomposisi rendah, maka nilai COD di hilir bisa menjadi tinggi. Untuk penggunaan air minum terdapat kriteria kebauan. Kebauan ini dapat berasal dari proses penguraian senyawa organik oleh bakteri. Dalam penguraian zat organik tersebut berakibat pada peningkatan penggunaan okesigen dalam air. Tingginya konsumsi oksigen dalam proses kimia menunjukkan kontaminasi pencemar organik (Senila et al., 2007).

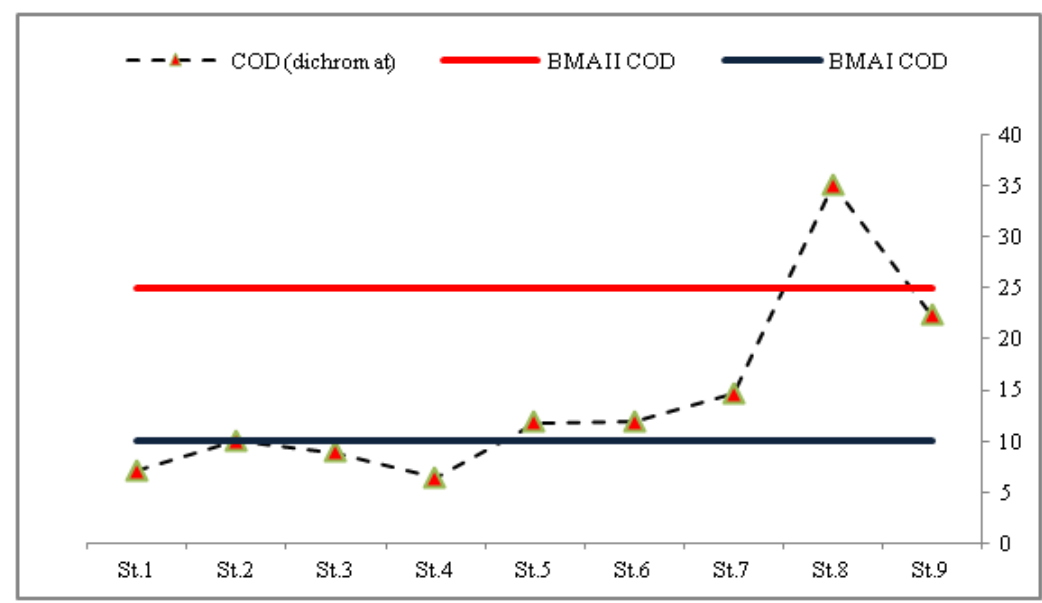

Gambar 4 Nilai COD Sungai Krukut, April 2015

\section{Coliform dan Fecal Coliform}

Bakteri coliform dalam air minum diklasifikasikan menjadi tiga jenis, yaitu coliform total, fecal coliform, dan E. coli. Coliform total termasuk bakteri yang ditemukan dalam tanah, air yang telah dipengaruhi oleh permukaan air, dan limbah manusia maupun hewan. Fecal coliform merupakan kelompok dari coliform total tetapi lebih spesifik hanya untuk bakteri yang juga dapat hidup dalam saluran pencernaan atau kotoran manusia ataupun hewan berdarah panas. Oleh karena asal usul dari fecal coliform lebih spesifik, maka fecal coliform dianggap sebagai indikator yang lebih akurat untuk menentukan kontaminasi air oleh kotoran manusia atau hewan berdarah panas dibandingkan dengan total coliform. Jenis yang ketiga ialah Escherichia coli (E. coli), merupakan spesies yang utama dalam kelompok fecal coliform, dari lima kelompok umum bakteri coliform, hanya $E$. coli yang umumnya tidak bereproduksi dan tumbuh di lingkungan, sehingga $E$. coli dianggap sebagai spesies bakteri coliform untuk indikator terbaik dari pencemaran tinja dan kemungkinan disertai adanya bakteri yang patogen (New York State Department of Health, 2011).

Coliform adalah golongan bakteri yang merupakan campuran antara bakteri fekal dan bakteri non fekal. Banyak strain E. coli yang beberapa diantaranya tidak berbahaya, terdapat pada saluran gastrointestinal pada manusia atau hewan berdarah panas. Tetapi ada beberapa kategori $E$. coli yang bersifat beracun, dan dapat menyebabkan diare (Said, 2008). PP No. 82/2001 menetapkan jumlah Total Coliform yang diperbolehkan untuk mutu air kelas I sebesar $1000 \mathrm{jml} / 100 \mathrm{ml}$, dan $5000 \mathrm{jml} / 100 \mathrm{ml}$ untuk mutu air kelas II, sehingga kandungan Total Coliform yang ada di Sungai Krukut sudah sangat jauh melebihi baku mutu air kelas I maupun kelas II (Gambar 5).

Kotoran manusia merupakan bagian yang paling berbahaya dari limbah domestik. Mikroorganisme patogen yang terkandung dalam tinja dapat menularkan beragam penyakit bila masuk tubuh manusia (Yudo, 2010). Keberadaan E. coli di perairan dipengaruhi oleh parameter fisika dan kimia. Curah hujan, temperatur, pH, salinitas, oksigen terlarut, phospor, dan padatan tersuspensi (Benndorf et al., 2000; Waluyo, 2009) merupakan faktor yang dapat mempengaruhi perkembangan bakteri E. coli di dalam suatu perairan (Baherem, 2014). 


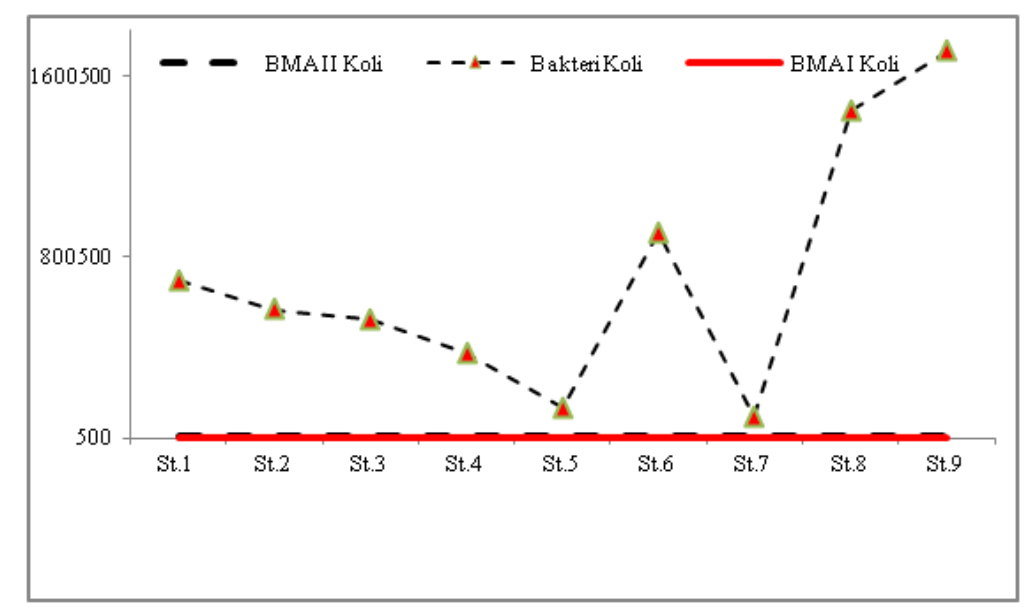

Gambar 5 Nilai coliform Sungai Krukut, April 2015

Kandungan fecal coliform yang ditetapkan pada PP. No. 82/2001 ialah 100 jml/100ml untuk air kelas I, dan $1000 \mathrm{jml} / 100 \mathrm{ml}$ untuk air kelas II. Jika dilihat dari nilai baku mutu yang ada, nilai fecal coli yang ada di Sungai Krukut sangat besar sehingga melebihi baku mutu yang telah ditetapkan baik baku mutu kelas I maupun kelas II (Gambar 6). Hal ini menunjukkan bahwa banyak limbah feces yang masuk ke dalam sungai, karena padatnya pemukiman kumuh di sepanjang aliran Sungai Krukut.

Bahaya secara langsung dapat terjadi akibat mengkonsumsi air yang tercemar, maupun menggunakan air tercemar untuk keperluan sehari-hari seperti mencuci peralatan makan dan sebagainya. Bahaya tidak langsung dapat terjadi misalkan mengkonsumsi hasil perikanan seperti mengkonsumsi ikan hasil memancing di sungai yang telah tercemar, dimana produk tersebut dapat mengandung polutan. Tingginya kandungan bakteri coli mengindikasikan Sungai Krukut tercemar oleh kotoran manusia dari aktivitas manusia di sepanjang sungai dan ketersediaan fasilitas pengolahan limbah yang kurang. Kondisi DKI Jakarta yang padat penduduk, serta pemukiman yang tidak terkelola dengan baik, dan banyak pemukiman kumuh di sepanjang aliran sungai menjadi faktor utama penyebab tingginya nilai coliform di sungai.

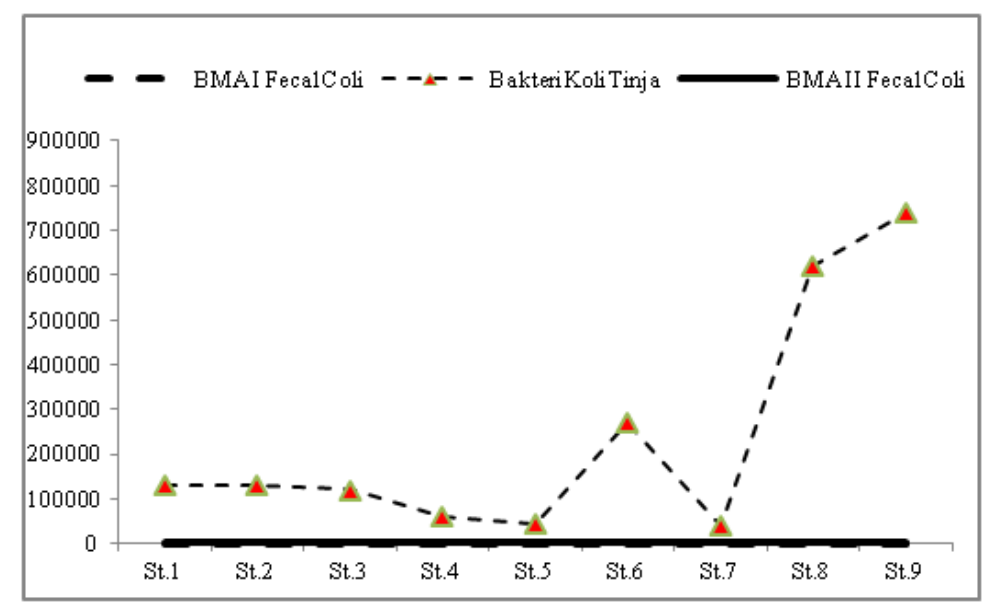

Gambar 6 Nilai fecal coliform Sungai Krukut, April 2015

\section{Indeks Pencemaran (IP)}

Jika dilihat pada Gambar 7, nilai IP pada Stasiun 1 sampai dengan Stasiun 3 memiliki nilai yang tidak jauh berbeda. Kemudian nilai IP turun pada Stasiun 4 dan Stasiun 5 meskipun masih berada pada kondisi cemar berat. Nilai IP mulai menunjukkan peningkatan pada titik Stasiun 6. Stasiun tersebut berada di wilayah yang sangat padat akan pemukiman dan juga perindustrian seperti hotel, cafe, dan perkantoran, yaitu berada 228 
di kawasan Kemang, sehingga nilai IP menjadi tinggi. Kemudian nilai IP turun pada Stasiun 7, lokasi ini berada di kawasan pemukiman yang teratur dan tidak terlalu dekat dengan badan sungai. Nilai IP kembali meningkat pada Stasiun 8 dan 9. Hal tersebut karena pada lokasi Stasiun 8 dan 9 merupakan kawasan padat penduduk dengan pola pemukiman yang tidak teratur dan beberapa ada yang menempel pada badan sungai, bahkan ada yang berada di atas badan sungai. Sehingga nilai IP pada Stasiun 8 dan 9 menjadi yang tertinggi diantara stasiun pemantauan yang lain.

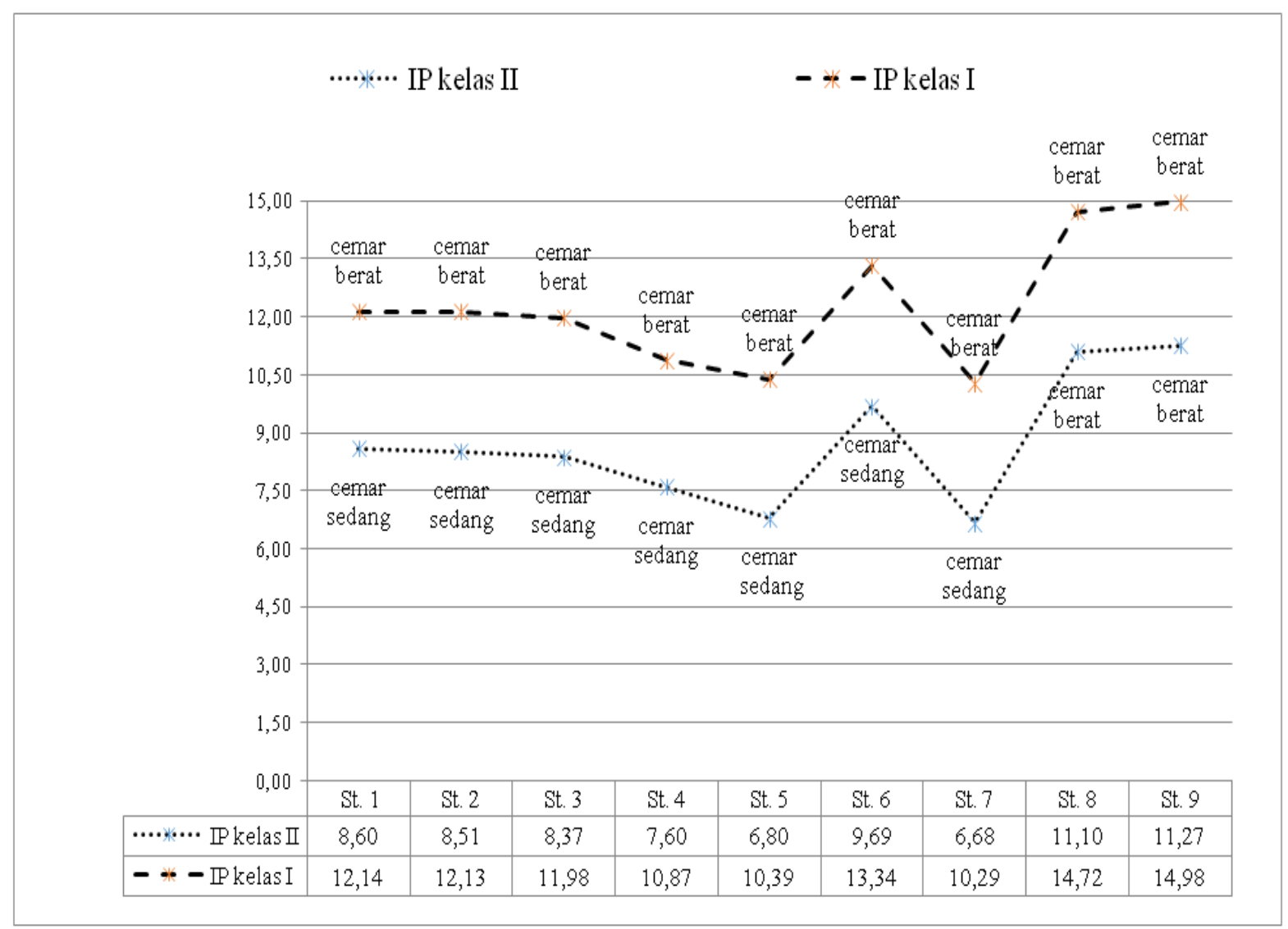

Gambar 7 Grafik status mutu Sungai Krukut tahun 2015 berdasarkan metode indeks pencemaran (terhadap BMA kelas I dan kelas II)

Jika menggunakan BMA kelas I, nilai IP menunjukkan bahwa status mutu air Sungai Krukut sudah tercemar berat di seluruh stasiun pemantauan, sehingga sudah tidak dapat digunakan sebagai bahan baku air minum. Diperlukan pengolahan dan treatment tertentu sebelum digunakan sebagai bahan baku air minum. Seperti yang telah dijelaskan di atas, pemerintah dapat bekerjasama dengan PT. Pam Jaya untuk mengolah air sungai sebelum digunakan sebagai bahan baku air minum.

Apabila menggunakan BMA kelas II, nilai IP pada stasiun 1 sampai 7 menunjukkan status mutu air Sungai Krukut berada pada cemar sedang, dan pada stasiun 8 dan 9 menunjukkan status cemar berat. Kondisi cemar sedang untuk kelas II menandakan bahwa air Sungai Krukut masih cukup aman apabila digunakan sesuai dengan peruntukkan air kelas II. Kualitas air pada stasiun 1 sampai 7 menunjukkan bahwa air Sungai Krukut masih memungkinkan untuk digunakan sebagai sumber air untuk perikanan, peternakan dan untuk mengairi tanaman. Pengelolaan air sungai perlu dilakukan untuk memperbaiki kualitas dan stastus mutu air sungai. Langkah yang perlu dilakukan ialah dengan mengurangi nilai beban pencemaran yang masuk sungai. Salah satu cara yang dapat dilakukan ialah secara fisik yaitu dengan membuat bangunan fisik seperti trap untuk sampah di setiap saluran air yang masuk ke sungai. 


\section{Potensi Beban Pencemaran Sungai Krukut}

Berdasarkan peta penggunaan lahan wilayah DAS Krukut segmen DKI Jakarta, penggunaan lahan di wilayah penelitian didominasi oleh permukiman. Hasil perhitungan beban pencemaran dari sektor permukiman di lokasi penelitian dapat dilihat pada Tabel 4. Total potensi beban pencemar Sungai Krukut dari sektor domestik sangat tinggi apabila dibandingkan dengan beban pencemar domestik Sungai Kalibaru Timur tahun 2015 yaitu $43715 \mathrm{~kg} / \mathrm{hari}$ untuk BOD, $60108 \mathrm{~kg} / \mathrm{hari}$ untuk COD, dan TSS sebesar $41529 \mathrm{~kg} / \mathrm{hari}$ (Pangestu, 2017).

Tabel 4 Potensi beban pencemaran BOD, COD, dan TSS

\begin{tabular}{lccc}
\hline \multicolumn{1}{c}{ Kecamatan } & BOD $(\mathrm{kg} / \mathrm{hari})$ & COD $(\mathrm{kg} / \mathrm{hari})$ & TSS $(\mathrm{kg} / \mathrm{hari})$ \\
\hline Gambir & 2468.48 & 4864.64 & 3361.02 \\
\hline Grogol Petamburan & 5346.80 & 1796.85 & 1241.46 \\
\hline Kebon Jeruk & 10921.11 & 15016.52 & 10375.05 \\
\hline Menteng & 1084.69 & 1491.45 & 1030.46 \\
\hline Pal merah & 8593.44 & 11815.98 & 8163.77 \\
\hline Tanah Abang & 6681.92 & 9187.64 & 6347.82 \\
\hline Kebayoran lama & 3636.06 & 4999.58 & 3454.26 \\
\hline Kebayoran baru & 122858.56 & 168930.50 & 116715.60 \\
\hline Mampang prapatan & 5798.56 & 7973.02 & 5508.63 \\
\hline Pancoran & 1835.10 & 2523.26 & 1743.35 \\
\hline Setiabudi & 4673.68 & 6426.31 & 4440.00 \\
\hline Tebet & 2757.89 & 3792.10 & 2619.99 \\
\hline Pasar Minggu & 6068.28 & 8343.89 & 5764.87 \\
\hline Cilandak & 8095.40 & 11131.18 & 7690.63 \\
\hline Jagakarsa & 12742.92 & 17521.52 & 12105.77 \\
\hline Total & 203562.89 & 275814.40 & 190562.70 \\
\hline
\end{tabular}

\section{Pembahasan}

Konsentrasi parameter pencemar yang paling tinggi di Sungai Krukut ialah parameter bakteri koli dan bakteri koli tinja. Apabila melihat kondisi Provinsi DKI Jakarta yang sangat padat penduduk maka tingginya limbah domestik yang masuk ke badan sungai merupakan hal yang mungkin terjadi. Ditambah dengan kurangnya penegakan hukum dan pelaksanaan Peraturan Pemerintah (PP) No. 20 Tahun 1990 dan PP No.82 Tahun 2001 tentang Pengelolaan Air dan Pengendalian Pencemaran Air, dimana diwajibkan semua air limbah domestik harus diolah terlebih dahulu sebelum dibuang ke saluran umum. Hal serupa juga tertulis dalam Keputusan Menteri Lingkungan Hidup No. 112 Tahun 2003 tentang Baku Mutu Air Limbah Domestik dimana setiap penanggung jawab usaha dan atau kegiatan permukiman rumah makan, perkantoran, perniagaan dan apartemen wajib melakukan pengolahan air limbah domestik sehingga mutu air limbah domestik yang dibuang ke lingkungan tidak melampaui baku mutu air limbah domestik yang telah ditetapkan.

Berdasarkan Indeks Pencemaran, kondisi status mutu kualitas air Sungai Krukut menunjukkan bahwa aktivitas manusia di sepanjang Sungai Krukut memberi pengaruh negatif terhadap kualitas air Sungai Krukut dan air Sungai Krukut tidak memenuhi kriteria untuk digunakan sebagai bahan baku air minum. Dengan jumlah penduduk sangat padat yang tidak disertai dengan pengelolaan tata ruang yang baik menyebabkan kualitas air sungai Krukut sangat buruk. Tata kota yang tidak teratur serta pertumbuhan penduduk yang sulit dikontrol merupakan penyebab dari penurunan kualitas air sungai di Jakarta. Laju pertumbuhan penduduk yang tinggi memicu munculnya permasalahan sosial ekonomi yang berdampak pada menjamurnya permukiman kumuh di sepanjang sempadan sungai. Sudah dapat dipastikan bahwa permukiman kumuh yang menjamur di sepanjang sungai tidak memiliki instalasi pengolahan air limbah komunal untuk mengolah limbah 
rumah tangga yang dihasilkan, sehingga limbah yang dihasilkan akan langsung terbuang ke badan sungai dan kualitas air sungai sudah dapat dipastikan akan semakin menurun. Hasil kualitas air Sungai Krukut menunjukkan hasil yang fluktuatif. Hasil buangan masyarakat pinggir sungai yang tinggi dapat mempengaruhi fluktuasi nilai kualitas air. Kegiatan masyarakat seperti mencuci, mandi, buang air dan membuang sampah langsung ke sungai juga merupakan faktor penyebab yang berpengaruh terhadap tinggi rendahnya nilai kualitas air. Di samping buangan dari aktivitas masyarakat di pemukiman pinggir sungai, kegiatan perkantoran, dan banyaknya ruko yang ada di sekitar sungai juga membuat nilai kualitas air sungai menjadi fluktuatif jika sanitasinya tidak dikelola dengan baik dan langsung dibuang di sungai.

Pada Gambar 10 dapat dilihat nilai kualitas air Sungai Krukut dari masing-masing stasiun. Dari gambar tersebut dapat dilakukan analisis bahwa di stasiun pertama, kedua, dan ketiga memiliki nilai yang hampir sama dan berada pada status tercemar berat. Kondisi di sekitar stasiun pemantauan memiliki kondisi serupa, yakni terdapat banyak outlet saluran drainase pembuangan air ke sungai dan terdapat sampah yang menumpuk di pinggir sungai, secara visual air sungai terlihat keruh. Pada stasiun kedua terdapat percabangan sungai yang menyebabkan dapat menjadi faktor penyebab kualitas air sungai menurun karena terdapat tambahan beban pencemaran dari aliran percabangan tersebut. Pada stasiun keempat dan kelima berada di dekat lokasi perumahan. Stasiun kelima berada di perbatasan perumahan elit dan permukiman kumuh padat penduduk dan terdapat kamar mandi umum yang berada tepat di pinggir sungai, sehingga pemerintah perlu untuk melakukan pembangunan IPAL komunal sehingga air dari permukiman ini tidak langsung dibuang ke dalam sungai. Nilai IP Sungai Krukut meningkat pada stasiun keenam. Stasiun tersebut berada di kawasan Kemang yang padat industri seperti apartemen, hotel, rumah makan, dan ditemui terdapat bangunan hotel yang sangat berimpitan dengan sungai. Perlu dilakukan pembatasan untuk izin usaha dan bangunan karena kawasan tersebut sudah terlalu padat yang berakibat pada menurunnya kualitas air Sungai Krukut yang melintasi kawasan tersebut. Nilai IP turun pada stasiun berikutnya meskipun masih berada pada status tercemar berat. Nilai IP naik pada stasiun kedelapan dan kesembilan yaitu pada bagian hilir Sungai Krukut. Pada stasiun terakhir merupakan perbatasan Sungai Krukut dengan Banjir Kanal.

Beban pencemar rumah tangga di Sungai Krukut merupakan hasil penjumlahan beban pencemaran seluruh kecamatan, sedangkan beban pencemaran setiap kecamatan dihitung menggunakan rumus (2). Berdasarkan peta penggunaan lahan yang diperoleh dari Dinas Pekerjaan Umum DKI Jakarta, penggunaan lahan DAS Krukut didominasi oleh pemukiman, dan dari penelurusan langsung di lapangan, diketahui bahwa industri yang berada di sekitar aliran Sungai Krukut merupakan industri yang hanya menghasilkan limbah domestik seperti kawasan pertokoan, apartemen maupun hotel. Oleh karena itu, beban pencemaran Sungai Krukut didominasi limbah domestik. Limbah domestik dapat bersumber dari kegiatan rumah tangga dimana saluran pembuangan langsung mengarah ke badan sungai dan sampah yang dibuang langsung ke badan sungai. Limbah domestik juga dapat berasal dari perkantoran dan industri yang berpotensi mengeluarkan limbah domestik (Hendrawan, 2005; Putra, 2013). Dari hasil penelitian yang dilakukan oleh P4L (Pusat Penelitian Pengembangan Perkotaan dan Lingkungan DKI Jakarta) disebutkan bahwa $80 \%$ sumber pencemaran sungai yang mengalir di Jakarta berasal dari limbah rumah tangga dan hanya $20 \%$ yang berasal dari buangan limbah industri (Susmarkanto, 2002). Pada Tabel 5 dapat dilihat bahwa beban pencemaran paling tinggi ialah pada Kecamatan Kebayoran Baru. Hal tersebut mungkin terjadi apabila dilihat dari jumlah penduduk Kecamatan Kebayoran Baru 3071464 jiwa. Besarnya beban pencemaran di Kebayoran Baru menandakan bahwa di samping jumlah penduduknya yang tinggi juga pengelolaan limbah yang kurang baik, sehingga diperlukan perhatian pemerintah daerah setempat untuk memperbaiki pengelolaan air limbah di wilayah tersebut. Begitupun pada wilayah kecamatan yang lain, dapat dilihat pada masing-masing kecamatan nilai potensi beban pencemar masih tinggi. 


\section{KESIMPULAN}

Status mutu air Sungai Krukut dengan menggunakan baku mutu air kelas I berada pada status tercemar berat, sedangkan apabila menggunakan baku mutu air kelas II, kualitas air Sungai Krukut berada pada status tercemar sedang hingga tercemar berat. Hal tersebut mengindikasikan bahwa air Sungai Krukut sudah tidak layak digunakan air baku air minum, sehingga diperlukan pengkajian ulang mengenai kebijakan peruntukan air sungai di Jakarta khususnya Sungai Krukut pada Pergub DKI Jakarta No. 582/1995. Selain itu perlu dilakukan treatment khusus terhadap air Sungai Krukut apabila dijadikan sebagai bahan baku air minum. Dalam kasus ini, pemerintah bekerja sama dengan instansi terkait seperti PT. PAM Jaya sebagai pihak pengelola air minum. PT. PAM Jaya mengolah air sebelum dikonsumsi oleh masyrakat, namun akan lebih baik jika pemerintah melakukan treatment pada air limbah sebelum dialirkan ke badan sungai. Di samping itu, pemerintah perlu untuk mendirikan fasilitas sanitasi seperti MCK umum di wilayah kumuh padat penduduk, serta mendirikan IPAL komunal di wilayah strategis di DKI Jakarta sehingga tidak akan mencemari sungai. Pengelolalaan selanjutnya yang dapat dilakukan oleh pemerintah DKI Jakarta ialah membuat aturan dengan sanksi berat mengenai larangan untuk membuang sampah di badan sungai, dan peningkatan jumlah dan kualitas tim pengeola sampah.

Potensi beban pencemaran di wilayah DAS Krukut berasal dari limbah domestik. Potensi beban pencemar domestik terbesar berasal dari Kecamatan Kebayoran Baru. Hal tersebut menandakan bahwa limbah domestik hasil dari aktivitas rumah tangga di wilayah tersebut tidak diolah secara baik sebelum masuk ke badan sungai.

\section{DAFTAR PUSTAKA}

[APHA] American Public Health Association. 2005. Standard methods for the examination of water and wastewater. 21st ed. American Public Health Association (APHA) and American Water Works Association, Water Environment Federation. Washington DC (US): USA Port City Press.

[BAPPEDA DKI JAKARTA] Badan Perencanaan Pembangunan Daerah. 2015. Seri Analisis Pembangunan Wilayah Provinsi DKI Jakarta. Jakarta (ID): BAPPEDA DKI Jakarta.

[BPLHD DKI Jakarta] Badan Pengelolaan Lingkungan Hidup DKI Jakarta. 2015. Buku Status Lingkungan Hidup Daerah DKI Jakarta Tahun 2015. Jakarta (ID): BPLHD DKI Jakarta.

[Kemenkes-RI] Kementerian Kesehatan Republik Indonesia. 2010. Peraturan Menteri Kesehatan No. 492/Menkes/Per/IV/2010 Tentang Persyaratan Kualitas Air Minum. Jakarta.

[PP] Pemerintah Indoensia. 2001. Peraturan Pemerintah No. 82 Tahun 2001 tentang Pengelolaan Kualitas Air dan Pengendalian Pencemaran Air. Sekretariat Negara. Jakarta.

[PerGub DKI Jakarta] Peraturan Gubernur. 1995. Peraturan Gubernur DKI Jakarta No. 582 Tahun 1995 tentang Penetapan Peruntukan dan Baku Mutu Air Sungai/Badan Air serta Baku Limbah Cair di Wilayah Daerah Khusus Ibukota Jakarta. Jakarta.

Amneera WA, Najib NWAZ, Yusof SRM, Ragunathan S. 2013. Water quality index of Perlis River, Malaysia. International Journal on Civil and Environmental Engineering. 13(2): 1-6.

Baherem. 2014. Strategi pengelolaan sungai berdasarkan daya tampung beban pencemaran dan kapasitas asimilasi - Studi kasus: Sungai Cibanten Provinsi Banten [tesis]. Bogor (ID): Institut Pertanian Bogor.

Effendi H, Romanto, Wardiatno Y. 2015. Water quality status of Ciambulawung River, Banten Province, based on pollution index and NSF-WQI. The 1st International Symposium on LAPAN-IPB. Satellite for Food Security and Environmental Monitoring Procedia Environmental Sciences. 24( 2015 ): 228-237.

Hendrawan D. 2005. Kualitas air sungai dan situ di DKI Jakarta. Makara Journal Of Technology Universitas Indonesia. 9(1): 13-19.

Iskandar I. 2007. Panduan Pelatihan Pengelolaan Kualitas Air. Jakarta (ID): Puslitbang Sumberdaya Air Kementerian Pekerjaan Umum.

Mahyudin, Soemarmo, Prayogo TB. 2015. Analisis kualitas air dan strategi pengendalian pencemaran air Sungai Metro di Kota Kepanjen Kabupaten Malang. J-PAL. 6(2): 105-114. 
Mara D. 2004. Domestic Wastewater Treatment in Developing Countries. London (GB): Earthscan.

Martinez F, Galera BIC. 2011. Monitoring and evaluation of the water quality of Taal Lake, Talisay, Batangas, Philippines. Academic Research International. 1(1): 229-236.

New York State Department of Health. 2011. Coliform Bacteria in Drinking Water Supplies [Internet]. [diunduh 2015 April 26]. Tersedia pada: health.ny.gov.

Pangestu R. 2017. Analisis daya tampung beban pencemaran Sungai Kalibaru Timur Provinsi DKI Jakarta, Indonesia [tesis]. Bogor (ID): Institut Pertanian Bogor.

Putra R. 2013. Kajian beban pencemaran dan kualitas air Sungai Batang Arau di Kota Padang [skripsi]. Bogor (ID): Institut Pertanian Bogor.

Said NI. 2008. Teknologi Pengelolaan Air Minum "Teori dan Pengalaman Praktis". Jakarta (ID): Badan Pengkajian dan Penerapan Teknologi.

Saksena DN, Garg RK, Rao RJ. 2008. Water quality and pollution status of Chambal River in National Chambal Sanctuary, Madhya Pradesh. Journal of Environmental Biology. 29(5): 701-710.

Salmin. 2005. Oksigen terlarut (DO) dan kebutuhan oksigen biologi (BOD) sebagai salah satu indikator untuk menentukan kualitas perairan. Oseana. 30(3): 21-26.

Senila M, Levei E, Miclean M, Tanaselia C, David L, Cordos E. 2007. Study regarding the water quality in Aries catchment. Chem. Bull. "POLITEHNICA" Univ. (Timişoara). 52(66): 169-172.

Setiyono. 2014. Pengelolaan Limbah Gedung Perkantoran Studi Kasus IPAL Gedung BPPT Jakarta. Jakarta (ID): BPPT Press.

Suriawiria U. 2003. Air dalam Kehidupan dan Lingkungan yang Sehat. Bandung (ID): Penerbit Alumni.

Susmarkanto. 2002. Pencemaran lingkungan perairan sungai salah satu faktor penyebab banjir di Jakarta (suatu tinjauan antropologis). Jurnal Teknologi Lingkungan. 3(1): 13-16.

Yudo S. 2010. Kondisi kualitas air sungai ciliwung di wilayah DKI Jakarta ditinjau dari parameter organik, amoniak, fosfat, deterjen dan bakteri coli. Jurnal Air Indonesia. 6(1): 34-42. 